\title{
On the formation of a mine-based energy resource complex
}

\author{
Volodymyr Falshtynskyi ${ }^{1}$, Roman Dychkovskyi ${ }^{1 *}$, Oleh Khomenko ${ }^{1}$, and Maksym Kononenko ${ }^{1}$ \\ ${ }^{1}$ Dnipro University of Technology, Department of Mining Engineering and Education, \\ 19 Yavornytskoho Ave., 49005 Dnipro, Ukraine
}

\begin{abstract}
The paper represents the analysis, which has helped to determine tendencies of the formation of energy resource complex based on the available mining facilities. The approach helps prolong operating life of the mine with the depleted balance reserves or the one being under abandonment. The proposed technologies of generator gas production by anaerobic digestion of organic raw material in the methane-tanks as well as other approaches to the combined formation of new energy systems make it possible to reorient the mine operation. The approach is extremely important for rather depressed mining regions as it helps solve the problem of social strain. Formation of the joint power and chemical production allows both improving economic expediency and preventing negative ecologic impact on surface and underground mine environment. The proposed tendencies make it possible to outline further issues to be highlighted in the following authors' studies.
\end{abstract}

\section{Introduction}

Current needs of the humanity in resources and energy are growing rapidly. That situation required creating new energy sources and technologies for their production. Innovative tendencies in the development of modern technologies in geoenergetics are necessary to get renewable energy sources and to develop secondary resources [1-4]. Energy-saving potential in Ukraine accounts for about $40 \%$ of the total energy market. Taking into consideration both current technological development and growing economic potential, volume of the renewable energy sources in Ukraine is $1.5-2.0$ bln tons of reference fuel being by 5 timed higher than the total national energy supply [5-8]. In this context, development and implementation of the renewable energy sources is at its initial stage while energy generation from those sources is only about $1.6 \%$ of the total world one [4, $9-10]$.

Considerable potential of the energy and secondary resources is accumulated within the technogenic underground and surface mine areas [11-15]. Transportation of the resources must be considered too [16-18]. Use of that potential is first of all connected with the mining sites and mines being either in stagnation or closed [19, 20]. Those technogenic territories are meant to be used for the development of mine energy resource complex (MERC) to produce energy and get secondary resources for the efficient and safe utilization of technogenic space of the mining enterprises [21-24].

\footnotetext{
* Corresponding author: dychkovskyi.r.o@nmu.one
} 
Formed within the technogenic mine area, the enterprises for generating electric and thermal energy and getting industrial products from the secondary resources and renewable energy sources consist of such modular and mobile segments of the complex low-waste production as $[25,26]$ :

1. Utilization of kinetic energy of wind flows of underground space, surface facilities, and waste dumps to generate electric energy;

2. Generation of electric energy by using kinetic flows of the underground space water;

3. Generation of electric energy by using renewable energy sources in terms of solarwind energy complexes;

4. Recuperation of the heat of rock mass, ground and waste water, and waste dumps;

5. Getting valuable elements from the secondary resources by implementing the technologies of heap, well, and block leaching;

6. Utilization and processing of organic waste with the help of gas generator plants within the underground space and purification and processing of the gasification products in terms of surface complex of the industrial mine site.

\section{Development of technologies during the formation of energy resource complex}

Previous studies paid considerable attention to the cogeneration technologies of the energy material production in terms of the operation of mining enterprises [9, 15, 21, 22, 27 - 29]. Possibility to apply heat pump generation, wind and solar energy generation, thermal energy use, use of differences in air flow temperature and pressure in the development mine workings, shafts, and on the surface as well as other technological improvements are analyzed in detail $[30,31]$.

Special attention is paid to the economic, environmental aspects of mining and geological activities, waste processing and development of technogenic deposits in terms of mining areas [32-36].

The use of software in establishing the geomechanical characteristics of the rock mas with examples of practical realization is described in the following works [27, $37-40]$. In works [41 - 43] special attention was given to combine different methods of geomechanical problems solving. This paper considers the possibilities of innovative technological improvements while forming the mine-based energy resource complex.

\subsection{Wind generation plants}

Cone-shaped waste dumps, covering the area of $50-1242$ ha and being $20-100 \mathrm{~m}$ high with average height value of $49.5 \mathrm{~m}$, are formed from the barren rock on the surface of the mine allotted territory [44-46]. In terms of those dumps, average natural air flow velocities reach $5.5-10.4 \mathrm{~m} / \mathrm{s}$; maximum velocities reach $15.6-22.7 \mathrm{~m} / \mathrm{s}$.

Special-purpose areas are formed on the prepared terricone surface to mount wind generation plants which are connected in a wind generation system (WGS) taking into account the conditions of wind energy capacity and mine dump unsuitability for the development [31]. Fig. 1 represents the technological scheme of such an energy system based on the mine dumps.

To utilize the energy of technogenic flows and wind and to mount the wind energy plants, facilities of the industrial mine site are used: roofs, mechanical floors, and areas of technogenic landscape of mining enterprises where air flows create the injection effect. 


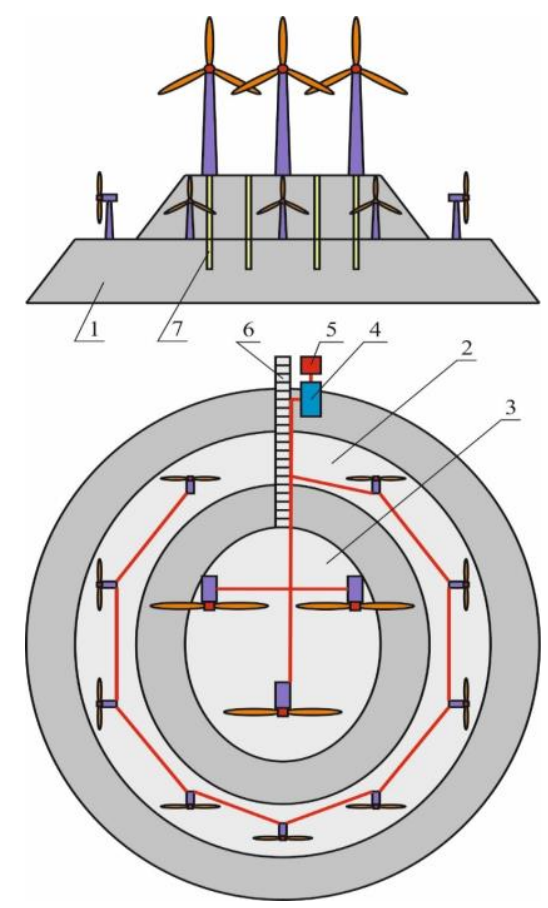

Fig. 1. Technological scheme of the energy system arrangement on the mine dumps basis: 1 - coneshaped dump of barren rock; 2 - area to mount wind generators with the wind wheel diameter of $D_{w . g}=2.5-3.2 \mathrm{~m}$ and capacity of $N_{w}=1.1-3.9 \mathrm{~kW} ; 3$ - area to mount main wind generators with the wind wheel diameter of $D_{w . g}=10-18 \mathrm{~m}$ and capacity of $N_{w}=9.6-50.4 \mathrm{~kW}$, covered with solar collectors; 4 - unit to control power contactors and chains; 5 - unit to sent the generated power to the electric network; 6 - monorail road; 7 - tubular thermal accumulator.

\subsection{Use of water space}

Ground water of the technogenic mine space is the potential renewable energy source. Accumulation of the considerable water volumes within the upper levels of the underground space favours accumulation of the potential energy of this energy carrier. Water pass throughout the wells, which lower mouths are equipped with hydroturbines with generators, transforms the kinetic energy of water flows into the electric one. Such a mine micro-HES consists structurally of the pass well reinforced with pipes; hydroturbine; generator; automatic systems to stabilize the output pressure and the flow start and stop; and a series of stop and ballast valves and other elements [21, 25]. Increase in the energy capacity of the flow will depend on the water level heads. Under those conditions, the output of hydroturbines is determined as follows:

$$
P_{t}=\gamma \frac{Q H}{\Omega} \eta_{t},
$$

where $\gamma$ is weight of the water volume unit, $\mathrm{kg} / \mathrm{m}^{3} ; Q$ is water consumption, $\mathrm{m}^{3} / \mathrm{s} ; H$ is operating head, $\mathrm{m} ; \Omega$ is angular rotation frequency, $\mathrm{rad} / \mathrm{s} ; \eta_{t}$ is overall turbine efficiency, $\%$.

The produced electric energy will be used for the MERC needs. Operating mode of the underground hydroelectric stations will depend on the peaks of electric energy consumption. In terms of maximum energy consumption, the system generates electric power while unloading the mine working from the accumulated water volumes. 
Collectors in the mine working of the upper level are filled by means of gravitational component; additional water volumes come from the lower levels. Water supply from the lower-level water collectors to the storage basins takes place within the period of the lowest energy consumption (Fig. 2). Table 1 represents calculation for one energy hydrounits of the underground hydroelectric station.

Table 1. Basic parameters of energy hydrounits of the underground hydroelectric station.

\begin{tabular}{|c|c|c|c|c|}
\hline Parameter & $\begin{array}{c}\text { Basin volume, } \\
\text { thous. } \mathrm{m}^{3}\end{array}$ & $\begin{array}{c}\text { Diameter of a drainage } \\
\text { well, } \mathrm{mm}\end{array}$ & $\begin{array}{c}\text { Incline angle of a } \\
\text { well, degree }\end{array}$ & Capacity, $\mathrm{m}^{3} / \mathrm{s}$ \\
\hline Value & $6.4-17.2$ & 280 & $80-85$ & 1.5 \\
\hline $\begin{array}{c}\text { Water } \\
\text { head, } \mathrm{m}\end{array}$ & $\begin{array}{c}\text { Hydrounit power, } \\
\mathrm{kW}\end{array}$ & $\begin{array}{c}\text { Hydrounit operation per } \\
\text { year, hour }\end{array}$ & $\begin{array}{c}\text { Working capacity } \\
\text { per year, } \mathrm{mW}\end{array}$ & $\begin{array}{c}\text { Efficiency of a } \\
\text { hydrounit, } \%\end{array}$ \\
\hline 58 & 776.7 & 2500 & 1942 & 0.91 \\
\hline
\end{tabular}

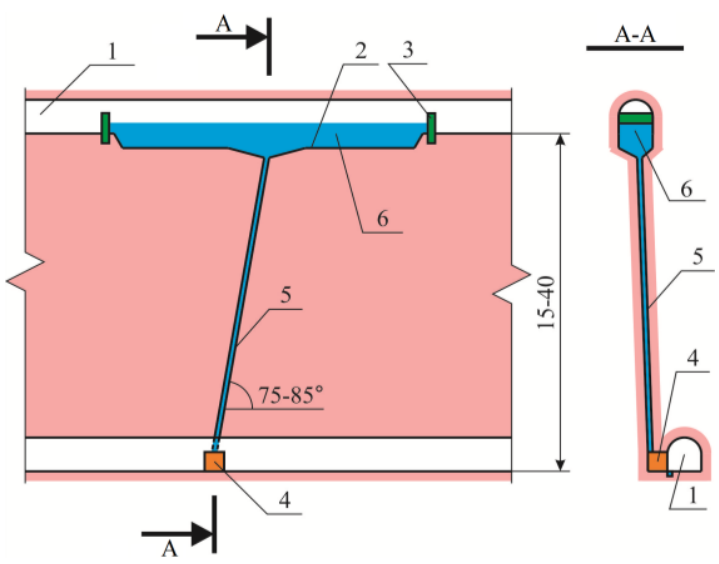

Fig. 2. Scheme of the underground HES to store the energy potential of the mine water: $1-$ mine roadway; 2 -water collector; 3 -water-resistant stopping; 4 -hydroturbine chamber; 5 -well; 6 - mine water.

\subsection{Systems for mineral raw material leaching}

Leaching methods improves considerably the economic, social, and ecological conditions of deposit mining as there is no need to construct mines [47-52] or open pits [53-58] as well as concentration plants and stockpiling of ore waste after its mining and processing. In this context, preservation of the major share of water resources within the deposit area plays an important role as well [59-61]. Essential social advantage of leaching methods is the overall change in the conditions, nature, and productivity of the operations, possibility of total mechanization and automation of a mining process, rational use of surface and underground resources [62 -64]. Underground leaching technology excludes the staff presence in the mine workings in terms of artificial ventilation and lighting. Moreover, it does not require hard manual work; it increases one-worker productivity by $1.6-1.7$ times, comparing to the openpit mining, and by 2 times in terms of underground ore mining $[65,66]$.

Analysis of the uranium production development opens possibilities for the application of advanced technologies and mining techniques by means of heap, block, and well leaching for other types of ores and resources, which are concentrated in the dumps of barren or low-grade ore and technogenic deposits [67, 68] with the determination of directive values as for each mining method according to the characteristics of the specified raw material (Fig.3) [69, 70]. 

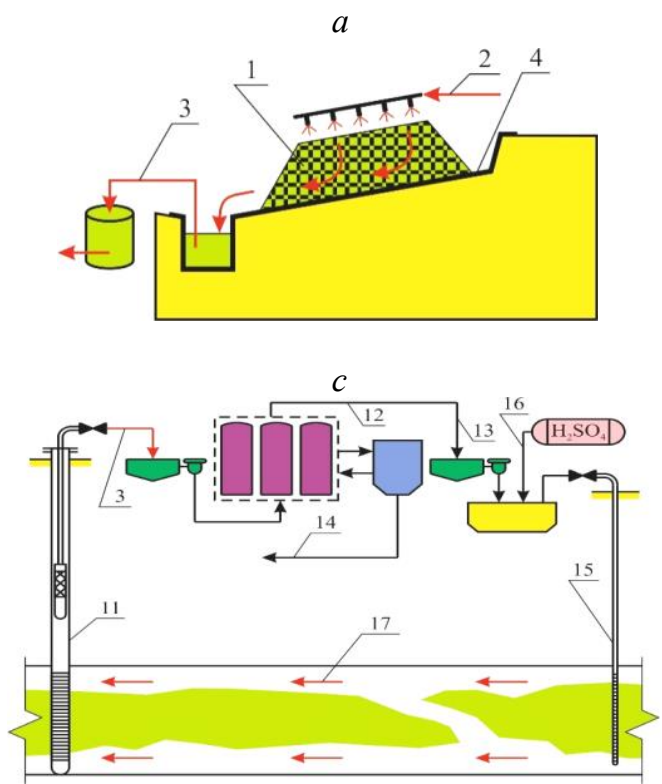

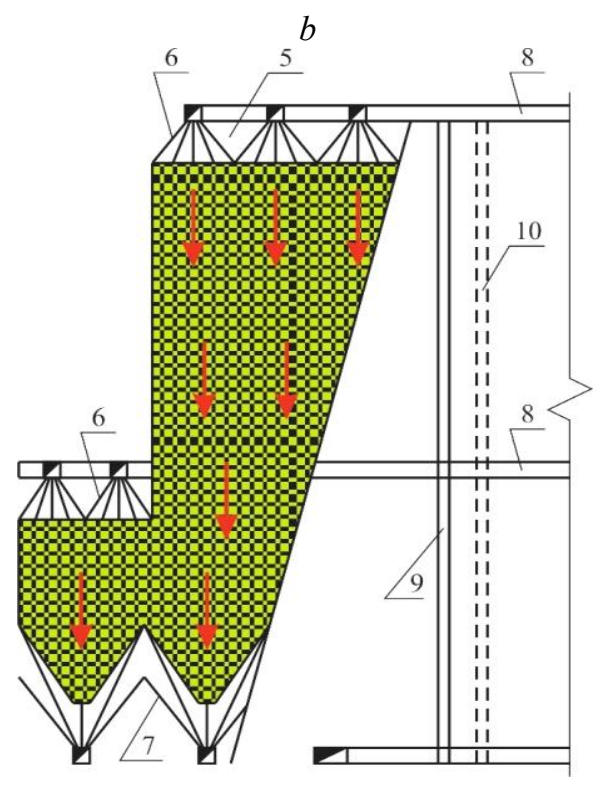

Fig. 3. Technological schemes of heap (a), block (b), and well (c) leaching of metals and elements: 1 - ore; 2 - leaching solution; 3 - product solution; 4 -impermeable layer; 5 -entry pillar; 6 - irrigation well; 7 - collecting wells; 8 -crossdrift; 9 -ore chute; 10 - hoisting; 11 -pump well; 12 - metal extraction from the solution; 13 -solution; 14 -metal concentrate; 15 -injection well; 16 - increasing concentration of $\mathrm{H}_{2} \mathrm{SO}_{4} ; 17$ - ore leaching in the deposit.

Basing on the data by the Ministry of Energy of the USA, uranium ore resources with the production cost of $33 \mathrm{USD} / \mathrm{kg}$ (oxide content is $U_{3} O_{8}=0.05 \%$ ) will increase by $9 \mathrm{mln} \mathrm{t}$ (uranium content in ores suitable for open-pit and underground development should be 0.12 and $0.22 \%$ respectively); in case of production cost being $66 \mathrm{USD} / \mathrm{kg}$, the increase will be by $56.3 \mathrm{mln} \mathrm{t}$ (in terms of the same uranium content in the ore); as for traditional mining methods, uranium content in the ore of that cost category should be not lower that $0.08 \%$. The initial capital costs for the underground mining complex (operational unit and plant to process solutions) with the capacity of $225 \mathrm{t}$ of $U_{3} O_{8}$ per year may be from USD $8 \mathrm{mln}$ up to USD $16 \mathrm{mln}$, including a share of research and production plants. The staff number is $60-100$ people while the traditional mining and metallurgical complex involves $300-500$ people. That is one more proof of the considerable potential while forming a mine-based energy complex to product that energy commodities.

\section{Development of the technological segments of a mine-based energy resource complex}

Technological segments of the MERC located within the industrial mine site provide the processing and utilization of secondary resources (solid and liquid organics, wastes of combustible and lubrication materials, sewage runoff, and organic waste). The segment is the combination of the technology for utilization and production of the gasification products and biogas $[8,71]$ making it possible to provide quality and mobility of the segment products (Fig. 4).

Gas generators for thermochemical processing and utilization of organic waste have become rather popular in the power generation sector, i.e. the process of gasificationburning at the temperatures of $800-1500{ }^{\circ} \mathrm{C}$. 


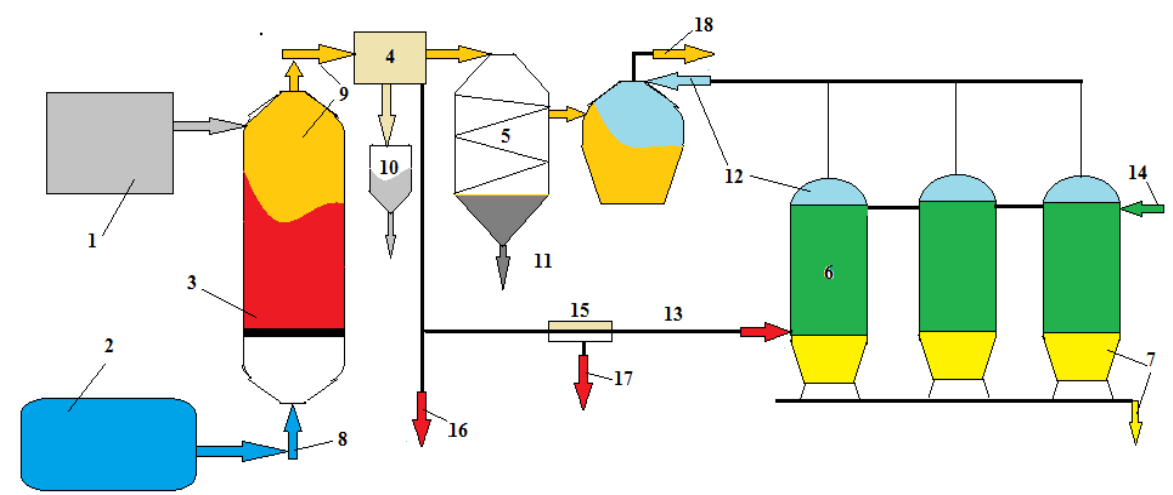

Fig. 4. Scheme of the MERC gas segment to produce generator gas by the gasification of wastes and biogas with the help of anaerobic digestion of organic raw material in methane-tanks: 1 - unit to supply organic raw material; 2 - unit to supply and prepare blowing; 3 - gas generator; 4 - unit for generator gas cooling; 5-unit to purify generator gas; 6-biogas plants; 7 -organic fertilizer; 8 - direction of blowing supply; 9 -direction of generator gas output; 10 - condensate; 11 -solid residue; 12 -direction of the generator gas output; 13 -heat supply for biogas plants $\left(T=30-500{ }^{\circ} \mathrm{C}\right) ; 14$ - direction of raw material supply; 15 - intermediate coolant; 16 - heat supply for the MERC needs $\left(240-425^{\circ} \mathrm{C}\right) ; 17$ - heat for the MERC needs $\left(172-368{ }^{\circ} \mathrm{C}\right) ; 18$ - supply of synthetic combustion gas for the MERC needs.

According to the analytic data, capacity of surface gas generator during the gasification of organic waste will be $2.17-3.82$ thous. of $\mathrm{m}^{3} /$ hour with the composition of combustible gases $\left(\mathrm{CH}_{4}, \mathrm{H}_{2}, \mathrm{CO}\right)$ of $26.8-63.1 \%$ and calorific value of $3.4-9.2 \mathrm{~mJ} / \mathrm{m}^{3}$.

A biogas plant consists of six methane-tanks with the capacity of $216.5-423.1 \mathrm{~m}^{3} /$ hour with the methane composition of $\mathrm{CH}_{4}-52.4-76.9 \%$ with calorific value of $15.8-21.3 \mathrm{~mJ} / \mathrm{m}^{3}$, and following fertilizer output: liquid $-2.8-5 \mathrm{t} /$ day, solid $-4.8-10.2 \mathrm{t} /$ day. Indices of changes in qualitative and quantitative parameters of synthesis gas during gasification in terms of the added methane component of biogas are shown in Fig. 5.

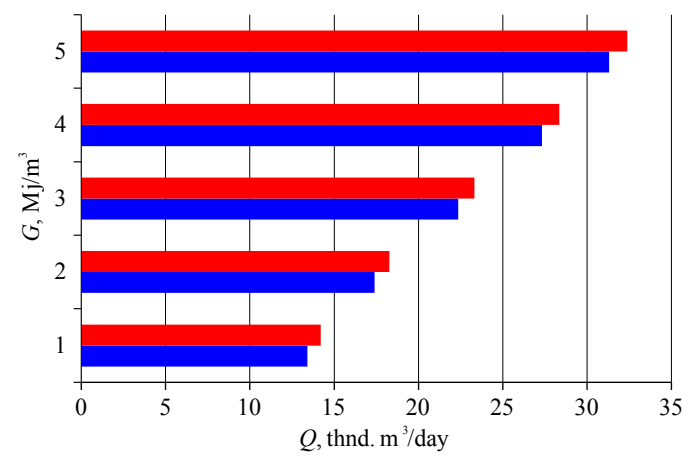

Fig. 5. Changes in the indices of quantitative and qualitative parameters of the combustible syngas components $\left(\mathrm{CH}_{4}, \mathrm{CO}, \mathrm{H}_{2}\right)$ in the MERC gas segment in terms of biogas adding to the generator gas depending on the blowing type during gasification: 1 -air; 2 -vapour; 3 -carbon-oxygen; 4 - vapour-oxygen; 5 - oxygen.

Synthesis gas generated in the segment may be used as the energy product, chemical raw material, and the material for electric and thermal energy production. The number of surface gas generators and biogas plants within the gas segment of the MERC complex will depend on the available raw material and needs of the complex in gas and energy product. 


\section{Conclusions}

Formation of the mine-based energy resource complex is one of the method to prolong the operating life of mining enterprises. Moreover, according to the studies, its structure and composition will depend on mining-geological and hydrological conditions; technical and engineering situation; climate of the territories; geographical location of the infrastructure etc. Apart from the considerable industrial importance, such an approach solves the important environmental problem as well. Mining of technogenic deposits, waste utilization, and development of the additional energy sources make it possible to highlight the economic component.

On the other hand, it is also possible to systematize basic tendencies of the functioning of a mine energy resource complex, which involve:

- utilization of kinetic energy of technogenic wind flows of the underground space, surface facilities, and rock dumps to generate electric energy;

- generation of electric energy by using kinetic flow of the underground-space water;

- generation of electric energy from the renewable energy sources by using solar and wind energy generation complexes;

- recuperation of the heat of rock mass, underground and sewage water, and rock dumps;

- getting valuable elements from the secondary sources by implementing the technologies of heap, well, and block leaching;

- utilization and processing of organic waste, involving gas generator plants within the underground space, and purification of the gasification products in terms of surface complex of the industrial mine site.

This work contains the research, which was conducted within the grant No 0120 U102084 (financed by the Ministry of Education and Science of Ukraine) and Dubrovnik International ESEE Mining School (projects within the framework of EIT Raw Materials).

\section{References}

1. Medunić, G., Mondol, D., Rađenović, A., Nazir, S. (2018) Review of the latest research on coal, environment, and clean technologies. Rudarsko Geolosko Naftni Zbornik, (33), 13-21. https://doi.org/10.17794/rgn.2018.3.2

2. Sobczyk, E.J., Kaczmarek, J., Fijorek, K., \& Kopacz, M. (2020) Efficiency and financial standing of coal mining enterprises in Poland in terms of restructuring course and effects. Gospodarka Surowcami Mineralnymi - Mineral Resources Management, 36(2), 127-152 https://doi.org/10.24425/gsm.2020.132565

3. Smil, V. (2015). A new world of energy. The Cambridge World History, 7(1), 164-184.

4. Gorova, A., Pavlychenko, A., Borysovs'ka, O., \& Krups'ka, L. (2013). The development of methodology for assessment of environmental risk degree in mining regions. Annual ScientificTechnical Collection - Mining of Mineral Deposits 2013, 207-209. https://doi.org/10.1201/b16354-38

5. Bondarenko, V.I., Kharin, Ye.N., Antoshchenko, N.I., \& Gasyuk, R.L. (2013). Osnovnye nauchnye polozheniya prognoza dinamiki metanovydeleniya pri otrabotke gazonosnykh ugol'nykh plastov. Naukovyi Visnyk NHU, (5), 24-30.

6. Law, B.E., Ulmishek, G.F., Clayton, J.L., Kabyshev, B.P., Pashova, N.T., \& Krivosheya, V.A. (1998). Basin-centered gas evaluated in Dnieper-Donets basin, Donbas foldbelt, Ukraine. Oil and Gas Journal, 96(47), 74-78.

7. Ovchynnikov, M., Ganushevych, K., \& Sai, K. (2013). Methodology of gas hydrates formation from gaseous mixtures of various compositions. Annual Scientific-Technical Collection-Mining of Mineral Deposits, 203-205. https://doi.org/10.1201/b16354-37 
8. Falshtynskyi, V.S., Dychkovskyi, R.O., Saik, P.B., Lozynskyi, V.H., \& Cabana, E.C. (2017). Formuvannia teplovykh poliv enerhokhimichnym kompleksom z hazyfikatsii vuhillia. Naukovyi Visnyk NHU, (5), 36-42.

9. Falshtynskyi, V., Saik, P., Lozynskyi, V., Dychkovskyi, R., \& Petlovanyi, M. (2018). Innovative aspects of underground coal gasification technology in mine conditions. Mining of Mineral Deposits, 12(2), 68-75. https://doi.org/10.15407/mining12.02.068

10. Pivnyak, G., Razumny, Y., \& Zaika, V. (2009). The problems of power supply and power saving in the mining industry of Ukraine. Archives of Mining Sciences, (54), 5-12.

11. Małkowski, P., Niedbalski, Z., \& Hydzik-Wiśniewska, J. (2013). The Change of Structural and Thermal Properties of Rocks Exposed to High Temperatures in the Vicinity of Designed GeoReactor. Archives of Mining Sciences, 58(2), 465-480. https://doi:10.2478/amsc-2013-0031

12. Majkherchik, T., Gajko, G.I., Malkowski, P. (2002). Deformation process around a heading investigation when front of longwall face advancing. Ugol (11), 27-29

13. Vladyko, O. (2012). Imitating modeling stability of mine workings. Geomechanical Processes During Underground Mining, 147-150. https://doi.org/10.1201/b13157-26

14. Dreus, A.Yu., Sudakov, A.K., Kozhevnikov, A.A., Vakhalin, Yu.N. (2016). Study on thermal strength reduction of rock formation in the diamond core drilling process using pulse flushing mode. Naukovyi Visnyk Natsionalnoho Hirnychoho Universytetu, (3), 5-10.

15. Dychkovskyi, R.O. (2015). Forming the bilayer artificially created shell of georeactor in underground coal well gasification. Naukovyi Visnyk Natsionalnoho Hirnychoho Universytetu, (5), 37-42.

16. Rakishev, B. R., \& Galiev, D. A. (2015). Optimization of the ore flow quality characteristics in the quarry in road-rail transport. Metallurgical and Mining Industry, 7(4), 356-362.

17. Taran, I.A. \& Klymenko, I.Yu. (2013). Transfer ratio of double-split transmissions in case of planetary gear input. Naukovyi Visnyk Natsionalnoho Hirnychoho Universytetu, (6), 60-66.

18. Taran, I.A., \& Klymenko, I.Y., (2014). Innovative mathematical tools for benchmarking transmissions of transport vehicles. Naukovyi Visnyk Natsionalnoho Hirnychoho Universytetu, (3), 76-81.

19. Caceres, E., \& Alca, J.J. (2016). Rural Electrification Using Gasification Technology: Experiences and Perspectives. IEEE Latin America Transactions, 14(7), 3322-3328. https://doi.org/10.1109/tla.2016.7587637

20. Caceres, E., \& Alca, J. J. (2016). Potential For Energy Recovery From a Wastewater Treatment Plant. IEEE Latin America Transactions, 14(7), 3316-3321. https://doi.org/10.1109/tla.2016.7587636

21. Bondarenko, V., \& Dychkovskiy, R. (2006). Methods of extraction of thin and rather thin coal seams in the works of the scientists of the underground mining faculty (National Mining Uuniversity). New Technological Solutions in Underground Mining International Mining Forum, 21-25. https://doi.org/10.1201/noe0415401173.ch3

22. Dychkovskyi, R., Vladyko, O., Maltsev, D., \& Cáceres Cabana, E. (2018). Some aspects of the compatibility of mineral mining technologies. Rudarsko Geolosko Naftni Zbornik, 33(4), 73-82. https://doi.org/10.17794/rgn.2018.4.7

23. Chernai, A.V., Sobolev, V.V., Chernai, V.A., Ilyushin, M.A., \& Dlugashek, A. (2003). Laser ignition of explosive compositions based on di-(3-hydrazino-4-amino-1,2,3-triazole)-copper(II) perchlorate. Combustion, Explosion and Shock Waves, 39(3), 335-339. https://doi.org/10.1023/A:1023852505414

24. Sobolev, V. (2020). Reasons for breaking of chemical bonds of gas molecules during movement of explosion products in cracks formed in rock mass. International Journal of Mining Science and Technology, 30(2), 265-269. https://doi.org/10.1016/j.ijmst.2020.01.002

25. Dychkovskyi, R., Tabachenko, M., Zhadiaieva, K., \& Cabana, E. (2019). Some aspects of modern vision for geoenergy usage. E3S Web of Conferences, (123), 01010. https://doi:10.1051/e3sconf/201912301010 
26. Beshta, O.S. (2012). Electric drives adjustment for improvement of energy efficiency of technological processes. Naukovyi Visnyk Natsionalnoho Hirnychoho Universytetu, (4), 98-107.

27. Dychkovskyi, R.O. (2015). Determination of the rock subsidence spacing in the well underground coal gasification. Naukovyi Visnyk Natsionalnoho Hirnychoho Universytetu, (6), 30-36

28. Lozynskyi, V.G., Dychkovskyi, R.O., Falshtynskyi, V.S., Saik, P.B., \& Malanchuk, Ye.Z. (2016). Experimental study of the influence of crossing the disjunctive geological faults on thermal regime of underground gasifier. Naukovyi Visnyk Natsionalnoho Hirnychoho Universytetu, (5). 21-29.

29. Falshtyns'kyy, V., Dychkovs'kyy, R., Lozyns'kyy, V., \& Saik, P. (2013). Justification of the gasification channel length in underground gas generator. Annual Scientific-Technical CollectionMining of Mineral Deposits, 125-132. https://doi.org/10.1201/b16354-22

30. Griadushchiy, Y., Korz, P., Koval, O., Bondarenko, V. (2007). Advanced Experience and Direction of Mining of Thin Coal Seams in Ukraine. Technical, Technological and Economical Aspects of Thin-Seams Coal Mining. https://doi:10.1201/noe0415436700.ch1

31. Cabana, E. (2018). A concept to use energy of air flows of technogenic area of mining enterprises. E3S Web of Conferences, 60 https://doi.org/10.1051/e3sconf/20186000004

32. Dychkovskyi, R.O., Avdiushchenko, A.S., Falshtynskyi, V.S., Saik, P.B. (2013). On the issue of estimation of the coal mine extraction area economic efficiency. Naukovyi Visnyk Natsionalnoho Hirnychoho Universytetu, (4), 107-114.

33. Gorova, A., Pavlychenko, A., Kulyna, S., \& Shkremetko, O. (2012). Ecological problems of postindustrial mining areas. Geomechanical Processes During Underground Mining, 35-40. https://doi:10.1201/b13157-7

34. Sarycheva, L. (2003). Using GMDH in ecological and socio-economical monitoring problems. Systems Analysis Modelling Simulation, 43(10), 1409-1414. https://doi.org/10.1080/02329290290024925

35. Bondarenko, V., Symanovych, G., \& Koval, O. (2012). The mechanism of over-coal thin-layered massif deformation of weak rocks in a longwall. Geomechanical Processes During Underground Mining, 41-44. https://doi.org/10.1201/b13157-8

36. Gornostayev, S.S., Crocket, J.H., Mochalov, A.G., \& Laajoki, K.V.O. (1999). The platinumgroup minerals of the Baimka placer deposits, Aluchin horst, Russian Far East. Canadian Mineralogist, 37(5), 1117-1129.

37. Shashenko, A., Gapieiev, S., Solodyankin, A. (2009). Numerical simulation of the elastic-plastic state of rock mass around horizontal workings. Archives of Mining Sciences, 54(2), 341-348.

38. Khomenko, O.Ye.( 2012). Implementation of energy method in study of zonal disintegration of rocks. Naukovyi Visnyk Natsionalnoho Hirnychoho Universytetu, (4), 44-54.

39. Kosobokov, O. (2018). A modern vision of simulation modelling in mining and near mining activity. E3S Web of Conferences, (60), 00014. https://doi.org/10.1051/e3sconf/20186000014

40. Vlasova, E., Kovalenko, V., Kotok, V., \& Vlasov, S. (2016). Research of the mechanism of formation and properties of tripolyphosphatecoating on the steel basis. Eastern-European Journal of Enterprise Technologies, 5(5(83)), 33-39. doi:10.15587/1729-4061.2016.79559

41. Pivnyak, G.G., Pilov, P.I., Bondarenko, V.I., Surgai, N.S., \& Tulub, S.B. (2005). Development of coal industry: The part of the power strategy in the Ukraine. Gornyi Zhurnal, (5), 14-17.

42. Smoliński, A. (2018). Mathematical and Geomechanical Model in Physical and Chemical Processes of Underground Coal Gasification. Solid State Phenomena, (277), 1-16. https://doi.org/10.4028/www.scientific.net/ssp.277.1

43. Sotskov, V., \& Saleev, I. (2013). Investigation of the rock massif stress strain state in conditions of the drainage drift overworking. Annual Scientific-Technical Collection - Mining of Mineral Deposits, 197-201.

44. Khalymendyk, I., \& Baryshnikov, A. (2018). The mechanism of roadway deformation in conditions of laminated rocks. Journal of Sustainable Mining, 17(2), 41-47. https://doi.org/10.1016/j.jsm.2018.03.004 
45. Su, C., \& Hu, Z. (2017). Reliability assessment for Chinese domestic wind turbines based on data mining techniques. Wind Energy, 21(3), 198-209. https://doi:10.1002/we.2155

46. Kononenko, M., \& Khomenko, O. (2010). Technology of support of workings near to extraction chambers. New Techniques And Technologies In Mining, 193-197. https://doi:10.1201/b11329-32

47. Borysovs'ka, O. (2014). Defining the parameters of the atmospheric air for iron ore mines. Progressive Technologies of Coal, Coalbed Methane, and Ores Mining, 333-339. https://doi.org/10.1201/b17547-57

48. Gorova, A., Pavlychenko, A., \& Borysovs'Ka, O. (2013). The study of ecological state of waste disposal areas of energy and mining companies. Annual Scientific-Technical Colletion-Mining of Mineral Deposits, 169-172. https://doi.org/10.1201/b16354-29

49. Myronova, I. (2015). The level of atmospheric pollution around the iron-ore mine. New Developments in Mining Engineering, 193-197. https://doi.org/10.1201/b19901-35

50. Buzylo, V., Pavlychenko, A., Savelieva, T., \& Borysovska, O. (2018). Ecological aspects of managing the stressed-deformed state of the mountain massif during the development of multiple coal layers. E3S Web of Conferences, (60), 00013. https://doi.org/10.1051/e3sconf/20186000013

51. Myronova, I. (2016). Prediction of contamination level of the atmosphere at influence zone of iron-ore mine. Mining of Mineral Deposits, 10(2), 64-71. https://doi.org/10.15407/mining10.02.0064

52. Khomenko, O., Kononenko, M., \& Petlovanyi, M. (2015). Analytical modeling of the backfill massif deformations around the chamber with mining depth increase. New Developments in Mining Engineering 2015, 265-269. https://doi:10.1201/b19901-47

53. Dryzhenko, A., Moldabayev, S., Shustov, A., Adamchuk, A., \& Sarybayev, N. (2017). Open pit mining technology of steeply dipping mineral occurences by steeply inclined sublayers. International Multidisciplinary Scientific GeoConference Surveying Geology and Mining Ecology Management, SGEM, 17(13), 599-606. https://doi.org/10.5593/sgem2017/13/s03.076

54. Galiev, S.Z., Galiev, D.A., Seitaev, E.N., \& Uteshov, E.T. (2019). Unified methodology for management of a geotechnological complex in open pit mining. Gornyi Zhurnal, (12), 70-75. https://doi.org/10.17580/gzh.2019.12.15

55. Sobko B., Lozhnikov O., Levytskyi V., \& Skyba G. (2019). Conceptual development of the transition from drill and blast excavation to non-blasting methods for the preparation of mined rock in surface mining. Rudarsko Geolosko Naftni Zbornik, 34(3), 21-28. https://doi.org/10.17794/rgn.2019.3.3

56. Galiyev, S.Zh., Dovzhenok, A.D., Kol'ga, A.S., Galiyev, D.A., \& Uteshov, E.T. (2019). Digitalization and the potential for improving the design and planning of mining operations in open cast mining. News of the National Academy of Sciences of the Republic of Kazakhstan, Series of Geology and Technical Sciences, 1(439). 146-154.

57. Belov, O., Shustov, O., Adamchuk, A., \& Hladun, O., 2018. Complex processing of brown coal in Ukraine: experience, practice, prospects. Solid State Phenomena, (277), 251-268. https://doi.org/10.4028/www.scientific.net/ssp.277.251

58. Levytskyi, V., Sobolevskyi, R., \& Korobiichuk, V. (2018). The optimization of technological mining parameters in a quarry for dimension stone blocks quality improvement based on photogrammetric techniques of measurement. Rudarsko Geolosko Naftni Zbornik, 33(2), 83-89. https://doi.org/10.17794/rgn.2018.2.8

59. Aben, E., Markenbayev, Zh., Khairullaev, N., Myrzakhmetov, S., \& Aben, Kh. (2019). Study of change in the leaching solution activity after treatment with a cavitator. Mining of Mineral Deposits, 13(4), 114-120. https://doi.org/10.33271/mining13.04.114

60. Malanchuk, Z., Moshynskyi, V., Stets, S., Ignatiuk, I., \& Galiyev, D. (2020). Modelling hydraulic mixture movement along the extraction chamber bottom in case of hydraulic washout of the puffstone. E3S Web of Conference. Preprint.

61. Lyashenko, V.I. (2001). Improvement of mining of mineral resources with combined leaching methods. Gornyi Zhurnal, (1), 28-35. 
62. Khomenko, O. Y., \& Kononenko, M. M. (2019). Geo-energetics of Ukrainian crystalline shield. Naukovyi Visnyk Natsionalnoho Hirnychoho Universytetu, (3). https://doi.org/10.29202/nvngu/2019-3/3

63. Pinnyak, G. (2020). Conditions of Suitability of Coal Seams for Underground Coal Gasification. Key Engineering Materials, (844), 38-48. doi:10.4028/www.scientific.net/kem.844.38

64. Khomenko, O., Kononenko, M., Kovalenko, I., \& Astafiev, D. (2018). Self-regulating roofbolting with the rock pressure energy use. E3S Web of Conferences, (60), 00009. https://doi:10.1051/e3sconf/20186000009

65. Zhanchiv, B. (2013). Substantiation of mining parameters of Mongolia uranium deposits. Naukovyi Visnyk Natsionalnoho Hirnychoho Universytetu, (4), 10-18.

66. Khomenko, O., Kononenko, M., \& Myronova, I. (2013). Blasting works technology to decrease an emission of harmful matters into the mine atmosphere. Annual Scientific-Technical Colletion Mining of Mineral Deposit, 231-235. https://doi.org/10.1201/b16354-43

67. Lyashenko, V.I. (2014). Ecological safety of uranium production in Ukraine Gornyi Zhurnal, (4), 113-116.

68. Lyashenko, V.I. (2003). Development of scientific foundations of nature- and resource-saving technologies for underground exploitation of uranium deposits. Metallurgicheskaya $i$ Gornorudnaya Promyshlennost, (1), 133-139.

69. Khomenko, O., Tsendjav, L., Kononenko, M., \& Janchiv, B. (2017). Nuclear-and-fuel power industry of Ukraine: production, science, education. Mining of Mineral Deposits, 11(4), 86-95. https://doi.org/10.15407/mining11.04.086

70. Lyashenko, V. (2018). Safety Improving of Mine Preparation Works at the Ore Mines. Bezopasnost' Truda v Promyshlennosti, (5), 53-59. https://doi:10.24000/0409-2961-2018-5-53-59

71. Bondarenko, V., Lozynskyi, V., Sai, K., \& Anikushyna, K. (2015). An overview and prospectives of practical application of the biomass gasification technology in Ukraine. New Developments in Mining Engineering, 27-32. https://doi.org/10.1201/b19901-6 